\title{
Security for the members of defined benefit pension schemes ${ }^{1}$
}

Received (in revised form): 3rd August, 2000

\section{Dr Deborah Cooper}

graduated with a degree in Mathematics from London University and then completed a PhD at the University of Wales. After working for the Government Actuary's Department and W. M. Mercer, she joined the Department of Actuarial Science and Statistics at City University as a lecturer, where this paper was written. She now works for W. M. Mercer. She is a Fellow of the Institute of Actuaries.

\begin{abstract}
This paper considers how members of defined benefit occupational pension schemes can be provided with security in the event of the sponsoring employer's bankruptcy. It considers the various forms of regulation in place in the EU and the USA and discusses their motivation and effectiveness. In particular, it considers how insolvency insurance contributes to member security.
\end{abstract}

Keywords: defined benefit pension scheme; regulation; insolvency insurance

\section{Introduction}

This paper is concerned with how regulation can be used to reduce the risks faced by members of defined benefit pension schemes, should the sponsoring employer become bankrupt at a time when the pension scheme has insufficient assets to secure its wind-up benefits.

In a 'free market', with perfect knowledge, there should be no need for external measures to provide security for members of defined benefit pension schemes. Employees would know and understand the nature of the risk faced if their employer's future was financially uncertain, and would demand higher wages than from an otherwise equivalent employer. We do not operate in such a free market. Most employees cannot dictate terms to an employer and would

Dr Deborah Cooper (WM Mercer Ltd, Telford House, Tothill Street, London SW1 9NB.

Tel: +44 (0)20 7977 8684; Fax: +44 (0)20 7977 8899; e-mail: deborah.r.cooper@ uk.wmmercer.com) have difficulty in assessing their employer's risk of bankruptcy, or in assessing an appropriate level of compensation for the risk they face. Instead, governments issue legislation aimed at controlling such risks. However, there is a fine balance to be struck, since excessive regulation can introduce new problems and hamper the development of appropriate retirement provision.

The role occupational pension schemes play in relation to government policy will affect what might be considered an appropriate level of regulation. If it is compulsory for employers to provide a pension scheme then, although additional regulation might have unfortunate economic consequences, it cannot be avoided except by ceasing business. If, on the other hand, pension provision is voluntary, employers can respond to additional regulatory burdens by ceasing to provide a pension scheme. Thus a measure to provide more security to employees in the event of one contingency (insolvency of the employer) could reduce the level of security in the event of another, more likely, contingency (retirement).

Similarly, government intervention might be more or less appropriate depending on the role the pension 
scheme fulfils in relation to state provision. Most countries provide state pensions at a minimal level, at least, and some also ensure that there are additional, salary-related, retirement incomes. In those countries where the government has legislated for a 'reasonable' level of provision, one might argue that there is less cause for intervention in private provision above that level. On the other hand, if private provision is a substitute for state provision, or if state provision stops at a low level, it is more reasonable to justify intervention.

When a defined benefit pension scheme's sponsoring employer becomes bankrupt, members face the risk that there are insufficient assets to secure the expected benefits. This can arise due to non-payment of contributions, misappropriation of funds, or due to historic underfunding, or unanticipated poor experience. ${ }^{2}$ Insolvency insurance can compensate for these risks, whereas more general forms of regulation are aimed at avoidance of the first two risks, and a reduction of the latter two. Only a small number of countries in the EU have compulsory insolvency insurance, and its cover is generally limited to those pension arrangements that are funded through book reserves.

In all cases the insurance applies only to plan terminations that arise as a result of the sponsoring employer's bankruptcy and in no case is the premium calculated on a wholly market-related basis.

When premiums are not directly risk-related, insurance can introduce selection problems. For example, where a pension scheme's liabilities are backed by explicit investment funds, the premium for insolvency insurance should be related to the size of the unfunded liability, otherwise employers have less incentive to fund the scheme adequately. The premium should also be related to the company's credit rating. Regulation can protect the insurer against the risk of adverse selection. However, it is probably true that the risk cannot be removed entirely, since even market-priced premiums are likely to involve elements of approximation. The most common forms of regulation are:

- regulating the establishment of an occupational pension scheme

- ongoing regulation of the scheme

— involvement of skilled professionals

- disclosure requirements

— establishment of a fund of assets.

In the next section these strategies are considered, with particular reference to how they can protect the security of members of funded defined benefit pension schemes.

\section{Funded pensions schemes}

It is generally accepted that the insurance market provides the 'gold standard' for security. This level of security comes at a cost. For example, insurance companies have to fulfil stringent disclosure requirements; they must establish solvency margins in addition to the expected value of their liabilities; and their freedom of action in satisfying regulatory requirements is curtailed.

Members of pension schemes do not generally have such a high degree of security. One problem arises since, while defined benefit schemes have rules that set out the benefits members are entitled to under various contingencies, members' 'expectations' often centre on remaining in employment until retirement, and so can be significantly different. In particular, when an employer becomes insolvent, even if there is not a shortfall of assets in the pension fund, 
members' expectations will often be significantly different to the eventual benefit they receive. This represents a misunderstanding of a pension scheme's ability to provide, which could lead to poverty in retirement. In this instance, better disclosure could reduce the risk that employees save too little because they overestimate the pension scheme's ability to provide in all circumstances.

If a pension scheme has been regulated as an insurance company, then the scheme members' benefits should be secure, since the scheme will have had to comply regularly with asset, liability and solvency regulations. However, this form of regulation is rare and, because of the costs involved, possible only for larger employers. Where insurance company regulations do not apply, the level of insecurity can be controlled by the procedures mentioned in the introduction.

\section{Registration}

Even though some EU countries have compulsory pension provision that results in adequate replacement levels ${ }^{3}$ for all but the highly paid, most still recognise the need to encourage saving and, in particular, saving for retirement.

Consequently, it is common for people to be able to defer paying tax on contributions to, and investment returns in, certain forms of pension savings. In order to benefit from this, most EU countries require that employers who establish occupational pension schemes should register them with a supervisory authority, and that they should be set up in a particular way, satisfying regulations regarding the benefits they provide. These requirements have in common that the pension scheme is established as a separate legal entity from the employer, thus introducing the possibility of some independence in the pension scheme's decision making. However, until the Goode Report ${ }^{4}$ recommended otherwise, it was frequently the case in the UK that the Trustees of pension schemes tended to be appointed by, and often from among, the senior management of the employer. Since the passage of the 1995 Pensions Act, Trustee bodies would usually have at least one-third member representation. In other countries equal representation is required.

Another consequence of establishing the scheme separately from the employer is that a separate investment fund is accumulated. Although book reserved schemes are still the most common form of provision in Germany, several countries discourage, or prohibit, their use.

As well as ensuring a scheme is set up in an acceptable way, the process of registration can also be used to involve the employees in the establishment of the scheme. This often includes consultation with employee representative bodies. If carried out properly, this might ensure that employees accept and understand the scheme, and its limitations, reducing communication problems later on.

The issue of disclosure to members and to regulatory bodies is becoming increasingly important, and is covered in more detail later. Many countries have recently reviewed the level of information required at the formative stage, and introduced legislation with echoes of insurance company regulations.

Another requirement that must be met when a pension scheme is initially established is that benefits comply with legislation regarding vesting rights and non-discrimination. Immediate vesting, particularly when combined with indexation, can reduce problems caused by the discrepancy between benefits and expectations, mentioned above. 


\section{Ongoing regulation}

There are several aspects of the ongoing management of funded pension schemes that might be regulated, with the purpose of ensuring that schemes are able to pay the benefits expected by members under all the possible contingencies.

These include:

- a minimum funding requirement (MFR), which primarily protects a (usually) minimal level of benefit in the event of wind-up

— investment controls

- disclosure of information

- ensuring good management through, for example, regular funding reviews, regular provision of accounts and financial statements and appropriate management and financial control

- ensuring that those responsible for the day-to-day management of the scheme are properly regulated.

These forms of intervention operate more or less effectively, partly because some aspects are driven by governments' need to ensure a certain level of tax revenue, rather than the primary need to ensure members' security.

\section{Minimum funding requirements}

With a funded scheme, one ongoing requirement might be that the benefits are financed appropriately. With book reserve financing, this usually means that an appropriate reserve is set aside in the sponsoring employer's balance sheet, and that the employer purchases insolvency insurance. This begs the question: What is an 'appropriate' level of finance?

Most countries impose MFRs at the level of the accrued benefit obligation (ABO). Some countries impose both a calculation method and a basis. In theory, unless an ongoing scheme is quite mature, the level of funding is in some sense academic. The intention behind the regulation is that, should a pension scheme be wound up, there are 'sufficient' assets to provide members with some level of benefit. By applying the minimum funding test at the $\mathrm{ABO}$ level the intention is that members' benefits, based on service and salary at the date of closure, should be met. The choice of basis (in particular, the rate of investment return assumed) is crucial in determining how likely it is that schemes that meet the minimum funding target can also meet their members' benefit entitlements. Unless the assets of the pension scheme exactly match the liabilities, there can never be complete certainty. ${ }^{5}$ Pension scheme regulators could build-in implicit solvency margins by prescribing a cautious basis, but it might be better for such measures to be made explicit.

In the UK many actuaries recommend that Trustees fund pension schemes to 100 per cent of the projected benefit obligation (PBO). This anticipates, to some extent, the costs imposed by a scheme maturing, by spreading the cost over the lifetime of the plan. It also has the advantage of being less sensitive to fluctuations in investment returns than the ABO. However, to use this as a statutory target could be confusing, since members might expect that they are entitled to benefits including future salary escalation, in the event of wind-up. In addition, it would be harder to justify this calculation method to the Inland Revenue or accounting authorities, since in some respects a part of the $\mathrm{PBO}$ is truly a future service liability. Instead, it might be more appropriate to use an indexed benefit obligation, which is broadly what the MFR in the UK amounts to.

While the MFR in the UK might, in theory, be viewed as a reasonable target, in practice it has not been satisfactory. This is partly because it does not meet 
people's perceptions of what it should deliver, and partly due to its administrative complexity. More generally, any funding requirement that is geared towards security in the event of a scheme's closure will introduce a conflict between the long-term and short-term financing needs of the scheme.

Setting an MFR raises a further issue in the case of schemes that undershoot the target. Some guidance must be provided as to how the scheme must plan to increase its fund up to the prescribed minimum funding level. In the USA employers can amortise a past service deficit over as long as ten years, whereas in the UK, even though there is a higher funding target, employers have a maximum of five years. This implies very different levels of security for the members, and very different financing problems for the employer. A longer amortisation period reduces the scheme members' short-term security, but introduces a compromise between the short- and long-term financial obligations of the scheme's Trustees that might enhance the members' longer-term security.

\section{Asset regulations}

Many countries in the EU restrict the investment policy that a pension scheme can pursue. Governments choose to regulate the investment portfolios of pension schemes for several reasons. However, this paper is concerned with how it can improve members' security.

One way in which security can be improved is for the pension scheme to provide good 'value for money' for the employer. If the assets of the scheme work for the employer in the sense of keeping costs down, the employer is more likely to continue to support the scheme. Requiring a pension scheme to invest largely in government bonds would be expected to militate against this form of security.

On the other hand, government bonds are secure, in the sense that they will provide their expected redemption yield with a high degree of probability, and consequently reduce short-term volatility in funding. Table 1 gives the risk return ratio experienced by pension schemes in several EU countries and the USA, over the period 1984-93.

Note that those countries with least investment regulation (the USA, UK, Ireland and the Netherlands) appear to do best in terms of what might be considered long-term security and, with the exception of Ireland, also score well in terms of short-term security. In response to this type of analysis, the $\mathrm{EU}^{7}$ is proposing that investment regulation should be relaxed to the 'prudent person' norm in 'Anglo Saxon' regulatory regimes.

Individuals are vulnerable to the time period over which they invest and the financial conditions immediately prior to retirement in particular. In defined benefit schemes, investment risks are spread between members and the employer, and across generations, although members are still vulnerable to the effects of poor investment performance. In some countries where defined contribution pension provision is compulsory, such as Chile, the government guarantees a minimum level of investment return. This can be financed by prescribing that a minimum proportion of the assets must be invested in government bonds. ${ }^{8}$ In some ways, government-sponsored insolvency insurance is a similar measure, but applied to defined benefit schemes.

\section{Disclosure to members}

Before being able to mitigate the risks of pension scheme membership, one needs 
Table 1: Ranked risk return ratios, for $1984-93^{6}$

\begin{tabular}{lccl}
\hline & $\begin{array}{l}\text { Average pension } \\
\text { fund return }\end{array}$ & $\begin{array}{l}\text { Average standard } \\
\text { deviation }\end{array}$ & $\begin{array}{l}\text { Risk/return } \\
\text { ratio }\end{array}$ \\
\hline Sweden & 14.45 & 8.54 & 0.59 \\
US & 13.47 & 9.43 & 0.70 \\
UK & 15.48 & 11.37 & 0.73 \\
Netherlands & 9.53 & 7.16 & 0.75 \\
Belgium & 11.80 & 8.94 & 0.76 \\
Germany & 9.38 & 7.24 & 0.77 \\
Denmark & 9.99 & 9.39 & 0.94 \\
Ireland & 14.04 & 13.65 & 0.97 \\
Spain & 13.8 & 19.91 & 1.44 \\
\hline
\end{tabular}

to be aware of them. In the UK, and probably elsewhere, most individuals have a low level of understanding or knowledge of what retirement provision they can expect, whether from the State or from their occupational pension scheme. ${ }^{9}$ The British government has taken action to improve disclosure to scheme members, and the 1998 Green Paper 'A New Contract for Welfare' acknowledges the need to improve the general level of understanding about pensions. In fact, the UK seems to have a high degree of disclosure, with formal prescription of minimum disclosure stemming from the 1988 Pensions Act. Of course, it is more difficult to legislate for people to read and understand the literature they are given.

An alternative, or additional, means of providing some dissemination of information to scheme members is through employee representation. This is more common in continental Europe than in the UK, where occupational pension arrangements have often developed through a combination of paternalism and collective bargaining. This has resulted in pensions and related insurance and healthcare benefits becoming important parts of negotiations between management and labour. Consequently, the representation on pension scheme boards of management tends to be drawn from trade union or other representative employee groups, rather than directly from the membership of the scheme. Thus it is possible that, while their interests should coincide with those of the scheme members, they might also have other priorities. This could result in a failure of disclosure, and actions taken against the wishes of the membership, despite their apparent representation.

In addition, pension scheme provision and/or membership could be made compulsory. Given the complexity of many retirement benefit systems, the potential for individuals to make the wrong decision is so great that their welfare might be best protected by limiting the available choice. This is one of the motives behind the introduction of stakeholder pension schemes in the UK. Some European countries have gone a step further and made provision of defined benefit pension schemes by the employer (quasi) compulsory. Note that defined benefit schemes have high administration costs, particularly for small employers, and in countries where provision is compulsory most coverage is through industry-wide arrangements. One of the possible advantages of this form of provision is discussed later.

Disclosure should go beyond providing general information about the funding level and contributions paid to the scheme. For individuals to understand 
what their entitlements are under the various contingencies that could befall them, regular benefit statements are essential. If a benefit statement was combined with a statement of the scheme's funding level in relation to the MFR, this could provide quite powerful information.

\section{General supervision}

Insurance company regulations impose a requirement to produce regular data to enable regulators to assess solvency levels and to monitor financial and management probity. If data are inadequate, then regulators can intervene in the insurance company's management. The intention is to ensure the protection of policyholders, with whom the insurer has a contract. In addition, accounting regulations and rating agencies ensure that data are provided to shareholders, who can use the stock market to signal their view of an insurance company's management standards.

While some of this framework might be applicable to pension schemes, there are significant differences between insurance companies and defined benefit pension schemes: ${ }^{10}$

- insurance companies are providers of financial services, whereas pension schemes are consumers

— insurance companies have a contractual relationship with their policyholders, whereas the contractual relationship covering a pension scheme will be between the employee and the employer

- insurance companies guarantee nominal benefits, whereas pension schemes provide benefits based on levels of pay

- policies issued by insurance companies are usually for fixed premiums, whereas employers are often able to adjust the contribution they pay to a pension scheme

- pension schemes have no shareholders, except, perhaps, in the mutual sense, ${ }^{11}$ but do have the backing of the sponsoring employer(s)

- insurance companies are profit-making organisations, whereas pension schemes are not.

These differences do not mean that pension schemes require no regulation, but that a different model from the insurance regime might be more appropriate. For example, the Trustees (or equivalent) of a pension scheme are not expected to be experts, unlike the management of an insurance company. Trustees are permitted to delegate tasks to experts, such as fund managers and payroll administrators, who might already be subject to regulation, and whose performance is likely to be monitored by consultants employed by the Trustees.

The extent of regulation imposed on established pension schemes varies throughout the world. The heaviest burden is placed on those schemes that are regulated as insurance companies and, as has been mentioned, employers are becoming increasingly reluctant to provide pensions under these arrangements. In some countries, particularly those with a high level of compulsory cover, ongoing regulation is minimal. However, it is usual for registered pension schemes to have to provide annual accounts to the regulator.

\section{Insolvency insurance}

Those countries in Europe that insist that pension schemes purchase insolvency insurance do so only for book reserved schemes. Table 2 summarises the position. Note that, where insolvency insurance is provided, there are often limits to the cover. 
Table 2: Summary of insolvency provision for pension schemes in the EU

\begin{tabular}{|c|c|c|c|}
\hline & Main type ${ }^{(a)}$ & Financing & $\begin{array}{l}\text { Provision in the event of insolvency of the } \\
\text { sponsor and underfunding of scheme }\end{array}$ \\
\hline Austria & $\mathrm{DB}^{(\mathrm{b})}$ & $\begin{array}{l}\text { Mostly funded, but } \\
\text { some book } \\
\text { reserves }\end{array}$ & $\begin{array}{l}\text { Book reserve pension beneficiaries are } \\
\text { preferential creditors for earmarked assets }\end{array}$ \\
\hline Belgium & $\mathrm{DB}^{(\mathrm{c})}$ & Funded & \\
\hline Denmark & $\mathrm{DC}^{(\mathrm{d})}$ & Funded & \\
\hline Finland & DB & $\begin{array}{l}\text { Funded, or } \\
\text { insurance } \\
\text { arrangement }\end{array}$ & Insolvency insurance compulsory for $\mathrm{TEL}^{(\mathrm{e})}$ \\
\hline France & DB & $\begin{array}{l}\text { PAYG, with some } \\
\text { top-up funding }\end{array}$ & $\begin{array}{l}\text { Costs met by remaining employers in } \\
\text { scheme }\end{array}$ \\
\hline Germany & $\mathrm{DB}$ & $\begin{array}{l}\text { Funded (mainly } \\
\text { book reserves) }\end{array}$ & $\begin{array}{l}\text { Insolvency insurance compulsory in case of } \\
\text { book reserves }\end{array}$ \\
\hline Greece & DB & Funded & \\
\hline Ireland & $\mathrm{DB}$ & Funded & \\
\hline Italy & $D C^{(d)}$ & Funded & \\
\hline Luxembourg & DB & $\begin{array}{l}\text { Mainly book } \\
\text { reserves, some } \\
\text { funded }\end{array}$ & $\begin{array}{l}\text { Insolvency insurance compulsory in case of } \\
\text { book reserves }\end{array}$ \\
\hline Netherlands & DB & Funded & $\begin{array}{l}\text { For sector-wide schemes the cost will be } \\
\text { met by remaining sponsoring employers }\end{array}$ \\
\hline $\begin{array}{l}\text { Portugal } \\
\text { Spain }\end{array}$ & $\begin{array}{l}\mathrm{DB} \\
\mathrm{DC}^{(\mathrm{d})}\end{array}$ & Funded & \\
\hline $\begin{array}{l}\text { Spain } \\
\text { Sweden }\end{array}$ & $\begin{array}{l}\mathrm{DC}^{(d)} \\
\mathrm{DB}\end{array}$ & Funded & Credit insurance in case of book reserves \\
\hline UK & DB & $\begin{array}{l}\text { reserve } \\
\text { Funded }\end{array}$ & Only in case of fraud ${ }^{(f)}$ \\
\hline
\end{tabular}

Notes:

(a) DB is defined benefit and DC is defined contribution.

(b) Austria is the only country that permits book reserve schemes without insisting on the purchase of insolvency insurance.

(c) In Belgium, occupational pension schemes are regulated similarly to insurance companies.

(d) Defined contribution schemes are, by their nature, always fully funded.

(e) Although employers contribute to a fund for the compulsory TEL scheme, the assets are loaned back to employers, so that it is closer to book reserving than normal funding.

(f) This 'insurance' is funded by an after-the-event levy imposed on the pension scheme industry by the Pension Compensation Board.

Significant parts of the regulatory regime described in the 'Ongoing regulation' section rest on the existence of a separate fund of assets, so that employees can make decisions based on the nature of the underlying investments, the degree of funding and the contribution rates paid by the employer. As suggested, in an ideal world, employees could use this information together with information about the financial security of their employer to assess the relative values of different employment opportunities. The existence of insolvency insurance, particularly where premiums are not market-related, would be at best irrelevant: at worst it could distort the decision-making process.
However, in a world where employees are less able to assess competing employers and their pension schemes, there might be a role for insolvency insurance. In 1974 the Pension Benefit Guarantee Corporation (PBGC) was established in the USA to underwrite the benefits of occupational pension schemes. Its existence has not removed the need for regulation and, in fact, the regulatory regime in the USA is becoming increasingly expensive, to the extent that there has been a drift away from defined benefit pension provision.

With book reserving, disclosure of funding levels or contributions becomes irrelevant, and the existence of insolvency insurance fills the gap. 
Effectively, purchasing the insurance is an alternative to the funding decision. However, in none of the insolvency insurance arrangements we are aware of, is the premium paid for insurance calculated on a market-related basis, taking into account the credit risk of the employer. Thus it is not possible to make a direct comparison between the two forms of financing. Indeed, suppose a comparison is made between two employers, one funding a pension scheme in the UK mode, and another purchasing insolvency insurance in the German mode, say. Then the cost to the former is the cost of providing the benefits, as calculated by the actuary with due regard to the position of the scheme. The cost to the latter is related to the costs incurred by the insolvency insurer over the recent past: the PSVaG is funded on a pay-as-you-go (PAYG) basis, which is a function of insolvencies and inadequate investments elsewhere in the market, rather than anything to do with individual companies. The net effect might be closer to the French PAYG system, rather than a funded system.

In France, most employees are covered by one (or both) of two occupational pension schemes, AGIRC or ARRCO, which cover employees from a variety of industries. The schemes offer similar benefits, but cover different salary levels, financed on a PAYG basis. If a company becomes bankrupt, its employees remain in their scheme and the cost of paying their accrued benefits will be met by the remaining contributing employers. A similar arrangement occurs in the sector-wide schemes in the Netherlands, although the benefits are provided on a funded basis. Effectively, employers are grouping together to provide themselves with mutual insurance. However, while this seems as though employers have reached a high degree of accord with one another, in fact they have little choice. In France it is compulsory to provide occupational pensions and virtually all employers, apart from the largest, do so through schemes that cover a variety of industries or sectors. In the Netherlands, it is difficult for employers not to join a sector-wide scheme, where one is available, and so, effectively, employers have no choice in the matter. $^{12}$

\section{Conclusion}

With appropriate minimum funding and disclosure regulations in place and properly enforced, the likelihood that an employer could become bankrupt when its pension scheme has insufficient assets to meet its accrued liabilities should be small. Since it does not seem that a voluntary market for insolvency insurance exists, governments must decide whether it is reasonable for individual scheme members to bear this risk, or whether it should be removed or reduced through some form of insurance.

The PBGC's experience demonstrates that there are risks associated with insolvency insurance. It might turn out to be superfluous or counterproductive if effective safeguards already exist and it could provoke moral hazard. If premiums are not priced in a competitive market, the system can produce cross-subsidies from financially healthy to weak firms, causing a reduction in economic efficiency.

An alternative to insurance could be to improve disclosure. Together with well-chosen funding requirements, this could reduce, or even remove, the need for insurance.

Ensuring that those responsible for the good administration of a pension scheme are legally independent from the sponsoring employer can also help ensure each pension scheme's financial integrity. By imposing a well-thought-out and 
consistent regulatory regime, so that nonprofessional trustees, for example, can understand the limitations in which they can operate, and so that pension scheme members can understand their entitlements and have confidence that they will be met, the need for insolvency insurance can be reduced. However, such regulation is likely to impose costs on employers that some might feel unable to bear. In particular, small employers, who collectively employ the majority of the workforce in the UK, could be disinclined to provide defined benefit pension provision for their employees. Because of the additional risks faced by members of defined contribution pension schemes, this would be an unfortunate consequence of a regime intended to reduce risk.

One alternative might be to encourage industry-wide provision. There are significant economies of scale that can be achieved in defined benefit provision. Although this form of provision can involve cross-subsidies, its supporters argue that, by making pension provision part of the collective bargaining process, benefit standards and contribution rates should remain consistent with economic circumstances. The risks of selection bias and moral hazard are thus regulated by a process of openness and disclosure.

If it is felt desirable that scheme members should have complete certainty that their benefits will be met, some form of insurance seems essential. Unless such insurance can become affordable in the marketplace, there is certainly a case for government to become involved, at least up to a certain level of benefit. Such a commitment need not be expensive, provided appropriate regulation is in place.

\section{References}

1 This paper was financed by a Research Grant from the Institute and the Faculty of Actuaries.

2 In the UK, if underfunding has arisen due to non-payment of contributions by the employer, then this would be treated as a debt against the employer, and would rank alongside non-payment of pay. In some other countries, underfunding due to other causes would also rank quite highly as a debt on the employer. However, the degree of security that this offers employees is debatable, as payment of debt after bankruptcy can be delayed several years, and is often settled at a rate lower than par value.

3 Replacement level, the ratio of retirement income to final salary, is one way of measuring the adequacy of different modes of pension provision.

4 Report of the Pensions Law Review Committee, 1992, chaired by Prof. R. Goode.

5 If governments would issue bonds linked to increases in wages, employers could provide revalued career average pension schemes with little risk. Governments are well placed to do this, since part of their income derives from income tax.

6 De Ryck, K. (1996) 'European Pension Funds', European Federation for Retirement Provision.

7 For example, in the Green Paper, 'Supplementary Pensions in a Single Market'.

8 As discussed in Miles, D. and Timmermann, A. 'Risk Sharing and transition costs in the reform of pension systems in Europe', in 'Costing Pension Reform' (to appear).

9 Report of the Director General's Inquiry into Pensions, July 1997, Office of Fair Trading, Volume II.

10 Laboul, A. (1998) 'Private Pension Systems: Regulatory Policies', OECD.

11 In some countries pension schemes are established as non-profitmaking organisations and in Luxembourg the beneficiaries are considered the shareholders.

12 The ECJ case C-219/97 Maatschappij Drijvende Bokken BV v. Stichting Pensioenfonds voor de Vervoer-en Havenbedrijven. 